\title{
Evaluation of the Hydrological Parameters of the Kalako Fall on the Tinkisso River at Dabola (Republic of Guinea)
}

\author{
Doussou Lanciné Traore ${ }^{1}$, Yacouba Camara ${ }^{2}$, Sékou Camara ${ }^{2}$, Ansoumane Sakouvogui ${ }^{2,}$, \\ Mamby Keita ${ }^{3}$ \\ ${ }^{1}$ Polytechnic Institute, University Gamal Abdel Nasser the Conakry, Conakry, Guinea \\ ${ }^{2}$ Energy Department, Higher Institute of Technology of Mamou, Mamou, Guinea \\ ${ }^{3}$ Laboratory of Teaching and Research in Applied Energetics, Physical Department, Faculty of Sciences, University Gamal Abdel Nasser the \\ Conakry, Conakry, Guinea
}

Email address:

ansoumane2015@gmail.com (A. Sakouvogui)

${ }^{*}$ Corresponding author

\section{To cite this article:}

Doussou Lanciné Traore, Yacouba Camara, Sékou Camara, Ansoumane Sakouvogui, Mamby Keita. Evaluation of the Hydrological Parameters of the Kalako Fall on the Tinkisso River at Dabola (Republic of Guinea). International Journal of Sustainable and Green Energy. Vol. 7, No. 3, 2018, pp. 16-20. doi: 10.11648/j.ijrse.20180703.11

Received: November 13, 2018; Accepted: November 27, 2018; Published: December 28, 2018

\begin{abstract}
Assessment of the hydrological parameters of the Kalako waterfall on the Tinkisso-Dabola River by the 42-year data reconstruction method from 1971 to 2012. The year of calculation of hydrological parameters is 1989. The values of hydrological parameters (precipitation heights, flow volume and monthly flow) in this year from the site of Kalako determined, are zero in the months of December, January and February. They are minimal during the months of February $(8.0 \mathrm{~mm}$, $2.72 \times 10^{6} \mathrm{~m}^{3}$ and $\left.1.04 \mathrm{~m}^{3} / \mathrm{s}\right)$, April $\left(29.1 \mathrm{~mm}, 9.89 \times 10^{6} \mathrm{~m}^{3}\right.$ and $\left.3.81 \mathrm{~m}^{3} / \mathrm{s}\right)$ and November $\left(8.9 \mathrm{~mm}, 3.02 \times 10^{6} \mathrm{~m}^{3}\right.$ and $\left.1.16 \mathrm{~m}^{3} / \mathrm{s}\right)$. This results in a very small amount of water during these periods. On the other hand, during the period from May to October, the hydrological parameters of the site are important, with the maximum values observed in September $(333.42 \mathrm{~mm}$, $113.02 \times 10^{6} \mathrm{~m}^{3}$ and $43.75 \mathrm{~m}^{3} / \mathrm{s}$ ). These results show that, during the year of calculation, seven (7) months (April, May, June, July, August, September and October) out of twelve (12) of the Kalako site are very favorable for the production of hydroelectric power.
\end{abstract}

Keywords: Assessment, Hydrological Parameters, Rainfall, Volume and Flow

\section{Introduction}

Rain is essential for water balance studies as well as flow forecasting and simulation since it is used as input to hydrological models. Flow data provide information on regimes, extremes, past trends, and hydrological behavior of watersheds as part of the hydro-energy parameter assessment. Rain and flow are variable elements in time and space. A good spatio-temporal representation of flow and rainfall information is crucial for projections of hydroelectric dam construction [1].

Numerous studies have shown that the spatial and temporal variability of rainfall events can be significant. This rain is typically measured by rain gauges, which measure the amount of water precipitated at one point. For economic and practical reasons, it is unthinkable to install rainfall stations at each point in the watershed. An interpolation method is then needed to estimate an overall rainfall at the basin scale. Clearly, the efficiency of these interpolation methods will be conditioned by the sampling of this variable in time and space [2].

In the Republic of Guinea (West African water tower), the large quantities of annual rainwater are collected by a very dense hydrographic network of nearly 1165 rivers. Most of these rivers have their sources in the two mountains of the country (the Fouta-Djalon and the Guinean Ridge). They are divided into 23 river basins including 14 international basins (Figure 1). Water availability is summarized as follows: surface water (226 km³/year), groundwater (13 billion cubic meters) and rainwater (1988 mm/year) on average, unequally 
distributed, with peaks of 4000 to $4500 \mathrm{~mm}$ in Conakry and its surroundings [3].

The knowledge of the rainfall parameters of a hydroenergetic site makes it possible to deduce the hydrological characteristics of this site. These hydrological parameters are very important for the evaluation of the energy potential. The present research thus focuses on the evaluation of the hydrological parameters of one of the Kalako Falls on the Tinkisso-Dabola River by adopting the method of reconstituting rainfall data for a period of 42 years.

\section{Methodology}

\subsection{Presentation of the Study Area}

The Kalako Waterfall on the Tinkisso River is upstream of the Tinkisso hydroelectric power station in the Upper Guinea prefecture of Dabola (Figure 1). It is bounded on the north by the sub-prefecture of Banko, on the south by the Tinkisso hydroelectric power station, on the east by Souarela village and on the west by the city of Dabola. It is between $11^{\circ} 19$ 'west longitude and $10^{\circ} 66^{\prime}$ north latitude and is at an average altitude of $586 \mathrm{~m}$. The area of its watershed is $850 \mathrm{~km}^{2}$. The Kalako site is $10 \mathrm{~km}$ from the Tinkisso hydroelectric power station.

The left slope of the site has a slope of slight inclination, with a bedrock, covered by a small thickness of earth. The slightly altered gneiss appears on the side of the hill on nearly $595 \mathrm{~m}$. The rock outcrops widely in the right bank with a constant facies of gneiss-magmatic type very hard, unaltered [4]. The prefecture of Dabola is located in the center of the Republic of Guinea between the middle and the upper Guinea. The climate of Dabola is of the tropical type, characterized by the alternation of two seasons (rainy and dry). The average temperature in Dabola is $24.5^{\circ} \mathrm{C}$. The average annual rainfall is $1528 \mathrm{~mm}$ [4].

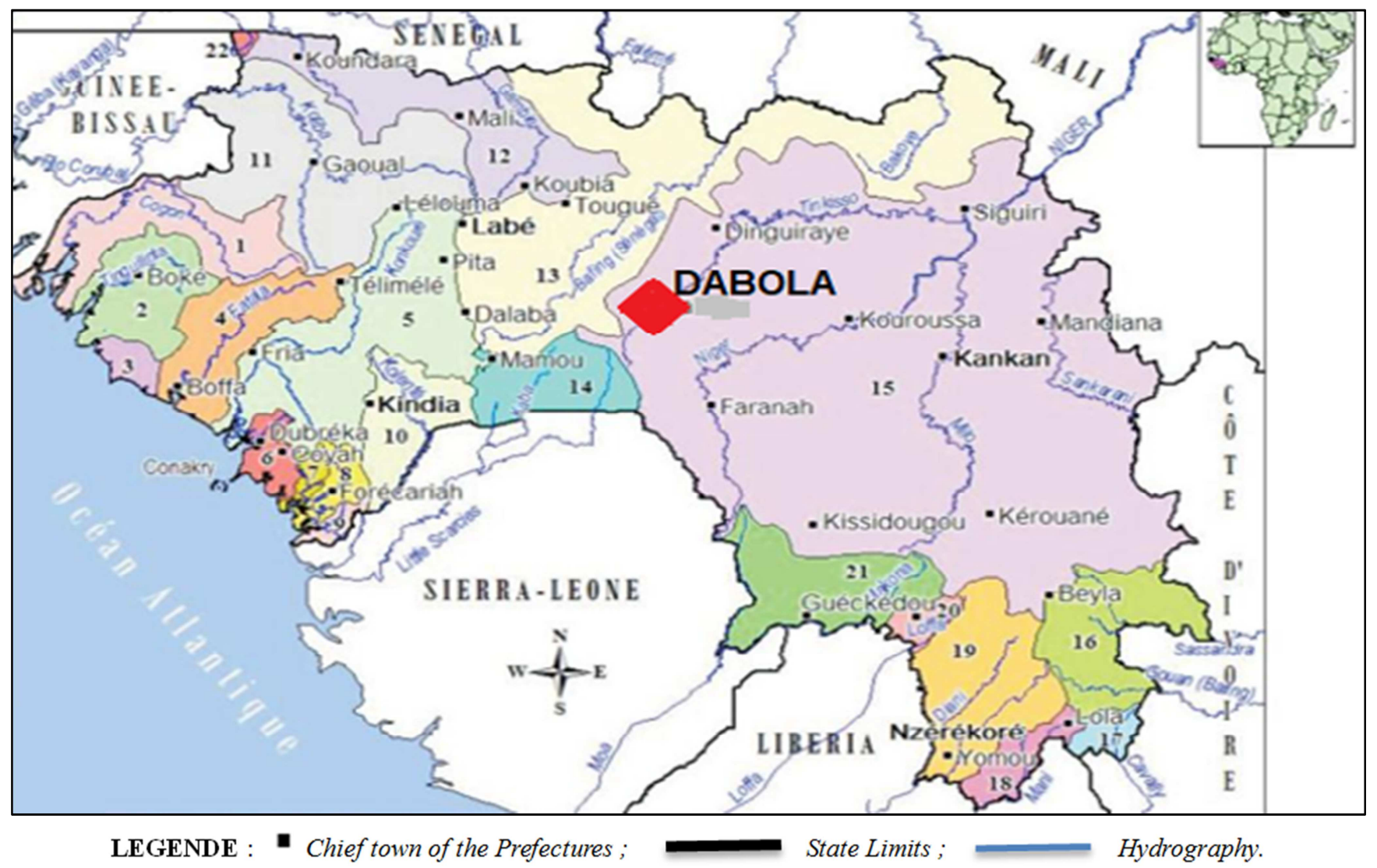

Figure 1. Map of Guinea with different watersheds.

Names of the watersheds: 1 Cogon; 2 Tinguilinta; 3 Kappatchez; 4 Fatala; 5 Konkouré; 6 Soumba; 7 Killy; 8 Forécariah/Bofon; 9 Melakhouré; 10 Kolenté; 11 Koloba/Korubal; 12 Gambie; 13 Sénégal; 14 Koba; 15 Niger; 16 Mani, 17 Samandra; 18 Mani; 19 Diani; 20 Loffa; 21 Makona; 22 Kayanga Géba.

\subsection{Method}

The determination of the main hydrological parameters (maximum operating and construction flows, monthly flow volumes, monthly flow flows and hydrographs) of a hydroelectric dam site is a function of the coefficients of variability, of the asymmetry, theoretical module and flow. These hydrological parameters are calculated as follows [5].

\subsubsection{Coefficient of Variability}

The coefficient of variability $(\mathrm{Cv})$ makes it possible to determine whether the number of years of the observation 
series is sufficient. It is determined by relation 1 [6].

$$
C_{v}=\sqrt{\frac{\sum\left(\mathrm{K}_{\mathrm{i}}-1\right)^{2}}{\mathrm{n}-1}}
$$

$\mathrm{K}_{\mathrm{i}}$ : is the theoretical module coefficient in (\%)

For: $\mathrm{n}=42$ years, the coefficient of variability calculated is $\mathrm{Cv}=0.35$.

\subsubsection{Coefficient of Asymmetry}

The asymmetry coefficient (Cs) is the measure of dispersion of values that globally quantifies differences between observations or their dispersion around a central value and determined by the relation 2 [7].

$$
\mathrm{C}_{\mathrm{s}}=\gamma \times \mathrm{C}_{\mathrm{v}}
$$

Where: $\gamma$ is constant which varies between 2 and 4 .

\subsubsection{Coefficient of Theoretical Module}

The theoretical modulus coefficient (Fi) corresponds to the coordinates of Foster RYBKINE, which is a magnitude that defines the rain surplus or deficit in an area in a given period. It is calculated by the relation 3 [8].

$$
\mathrm{F}_{\mathrm{i}}=\varphi \times \mathrm{C}_{\mathrm{v}}+1
$$

Where: $\varphi$ is the modulus factor given as a function of the probability (Pr), the probability of passing is expressed as a percentage, it is the probability of reaching or exceeding a quantity under examination. The values of the theoretical module $(\mathrm{Fi})$ are calculated for $\mathrm{Cs}=2$.

Table 1. Theoretical Module Coefficient (Fi).

\begin{tabular}{lllllllllllllllll}
\hline Pr & $\mathbf{0 . 1}$ & $\mathbf{1 . 0}$ & $\mathbf{5}$ & $\mathbf{1 0}$ & $\mathbf{2 0}$ & $\mathbf{3 0}$ & $\mathbf{4 0}$ & $\mathbf{5 0}$ & $\mathbf{6 0}$ & $\mathbf{7 0}$ & $\mathbf{8 0}$ & $\mathbf{9 0}$ & $\mathbf{9 5}$ & $\mathbf{9 9}$ & $\mathbf{9 9 . 9}$ \\
\hline$\varphi$ & 3.38 & 2.48 & 1.69 & 1.3 & 0.8 & 0.51 & 0.22 & -0.03 & -0.28 & -0.55 & -0.85 & -1.25 & -1.58 & -2.18 & -2.84 & 0.18 \\
$F_{i}$ & 2.18 & 1.86 & 1.59 & 1.45 & 1.28 & 1.17 & 1.07 & 0.88 & 0.90 & 0.80 & 0.70 & 0.56 & 0.44 & 0.23 & 0.006 \\
\hline
\end{tabular}

\subsubsection{Arithmetic Mean Squared Error}

The quadratic error is defined by the relation 4 . It is between 5 to $10 \%$ (Abdoul, 1996) [8].

$$
\sigma=\frac{C_{v}}{\sqrt{n}} \times 100
$$

Thus, the quadratic mean error is determined by the relation 5 (Abdoul, 1996) [8].

$$
\sigma_{q}=\sqrt{\frac{1+C_{v}^{2}}{2 n} \times 100}
$$

Thus: for $\mathrm{Cv}=0.35$ and $\mathrm{n}=42$, we find $\sigma=5.4 \%$ and $\sigma \mathrm{q}=$ $11.55 \%$. As $\sigma<10 \%$ and $\sigma q<15 \%$. This means that the number of years of observation (42 years) is sufficient.

\subsubsection{Coefficient of Flow and Its Choice}

The flow coefficient is the ratio between the amount of rain that has passed and the amount of water precipitated during a given period in a given basin. For tropical countries, this coefficient is between 0.2 and 0.6. In this search, we choose 0.4 .

\subsubsection{Maximum Operating and Construction Rates}

The maximum operating and construction rates are calculated according to the theoretical module coefficients (Houari, 2017) [9]. The maximum operating flow $\left(\mathrm{Q}_{\mathrm{i} \%}^{\max }\right)$ and the maximum design flow rate are calculated at $1 \%$ and $10 \%$ respectively. These flows are calculated by the relation 6.

$$
\mathrm{Q}_{\mathrm{i} \%}^{\max \exp }=\frac{\text { P.F. } \alpha}{\mathrm{T}}
$$

Where: $\mathrm{P}$ is the mean precipitation in $(\mathrm{mm})$ calculated from the relationship; $F=850 \mathrm{~km}^{2}$ is the surface of the watershed of the site; $\mathrm{T}=1$ month is the duration. The maximum operating flow at $1 \%$ is $72.25 \mathrm{~m}^{3} / \mathrm{s}$ and the maximum construction flow at $10 \%$ is $56.32 \mathrm{~m}^{3} / \mathrm{s}$. Average precipitation $(\mathrm{P})$ is defined by relation 7 [10].

$$
\mathrm{P}=\mathrm{P}_{0}^{\mathrm{int}} \times \mathrm{F}_{\mathrm{i} 1 \%}
$$

Where: $P_{0}^{\text {int }}=296.16 \mathrm{~mm}$ is the mean interannual precipitation; $\mathrm{F}_{\mathrm{i} 1 \%}$ is the theoretical modulus coefficient given in Table 1 [3]. Thus, for $\mathrm{F}_{\mathrm{i} 1 \%}$, we have: $\mathrm{P}=550.85 \mathrm{~mm}$ and for $\mathrm{F}_{\mathrm{i} 10 \%}$, we find $\mathrm{P}=429.43 \mathrm{~mm}$.

\subsubsection{Calculation Year}

The choice of the calculation year is based on the notion of mean annual precipitation (Pman). On the basis of this average, the table includes reconstructed rainfall data from the site, the year whose average annual rainfall is as close as possible to (Pman) [8].

\subsubsection{Average Annual Rainfall}

The average annual rainfall is calculated by the relation 8 [11].

$$
\mathrm{P}_{\text {man }}=\frac{\mathrm{P}_{\mathrm{i}}^{\mathrm{mes}}}{\mathrm{n}}
$$

Where: $\mathrm{P}_{\mathrm{i}}^{\mathrm{mes}}$ is the sum of the monthly precipitation from 1971 to 2012 (42 years).

\subsubsection{Volumes Mensuels d'écoulement}

The monthly flow volumes are defined by the relation 9 [12].

$$
\mathrm{W}_{\text {men }}^{\text {ecoul }}=\mathrm{H}_{\mathrm{p}}^{\text {men }} \times \mathrm{F} \times \alpha
$$

Where: $\mathrm{H}_{\mathrm{p}}^{\text {men }}$ is the sum of the monthly precipitation; $\mathrm{F}$ is the surface of the catchment area and $\alpha=0.4$ the flow coefficient of the study area. The calculation results of the monthly flow volumes are given in table 4 . 


\subsubsection{Monthly Flow Rates} [2].

The monthly flow rates are determined by the relation 10

$$
Q_{\text {ecoul }}^{\text {mens }}=\frac{\mathrm{W}_{\text {men }}^{\text {ecoul }}}{T}
$$

Where: $\mathrm{T}$ is the duration in seconds for a month of 30 days.

\section{Results and discussion}

\subsection{Results}

The results obtained are given in the tables and then represented by hydrographs.

Table 2. Average precipitation values for the calculation year.

\begin{tabular}{|c|c|c|c|c|c|c|c|c|c|c|c|c|c|}
\hline Month & Jan & Feb & Mar & Apr & May & Jun & Jul & Aug & Sep & Oct & Nov & Dec & Sum \\
\hline Pi (1971-2012) & 28.7 & 164.6 & 387.3 & 2213.6 & 4719.5 & 7321.3 & 10192.1 & 12826.6 & 11164.1 & 5683.5 & 913.7 & 32.98 & 55648.0 \\
\hline $\mathrm{P}_{\text {man }}$ & 0.68 & 3.91 & 9.22 & 52.70 & 112,36 & 174.31 & 242.66 & 305.39 & 265.81 & 135.32 & 21.75 & 0.78 & 1324.95 \\
\hline
\end{tabular}

The comparison of the sum of the mean annual rainfall $\left(\sum P_{\text {man }}=1324,95\right)$ with the sum of the annual precipitation of the reconstructed data, reveals that the year 1989 with a total of $1339.8 \mathrm{~mm}$ is best indicated as the year of calculation. The 1989 data are summarized in Table 3.

Table 3. Monthly Precipitation of the Calculation Year.

\begin{tabular}{llllllllllllll}
\hline Month & Jan & Feb & Mar & Apr & May & Jun & Jul & Aug & Sep & Oct & Nov & Dec & Sum \\
\hline Year 1989 & 0 & 8.0 & 0 & 29.1 & 147,2 & 184.8 & 201.0 & 244.2 & 333.6 & 183.0 & 8.9 & 0 & 1339.8 \\
\hline
\end{tabular}

The error allowed for the choice of the calculation year must be within $\pm 5 \%$. The calculation of this error for the 1989 selection is \pm 1 .

Precipitation heights, flow volumes, monthly flow rates for the year of calculation (1989) are given in Table 4.

Table 4. Precipitation Heights (Hp), Flow Volume (Wme), and Monthly Flow (Q).

\begin{tabular}{|c|c|c|c|c|c|c|c|c|c|c|c|c|}
\hline Month & Jan & Feb & Mar & Apr & May & Jun & Jul & Aug & Sep & Oct & Nov & Dec \\
\hline $\mathrm{H}_{\mathrm{p}}(\mathrm{mm})$ & 0 & 8.0 & 0 & 29.1 & 147.2 & 184.8 & 201.0 & 244.2 & 333.6 & 183.0 & 8.9 & 0 \\
\hline $\mathrm{W}_{\mathrm{me}}\left(10^{6} \mathrm{~m}^{3}\right)$ & 0 & 2.72 & 0 & 9.89 & 50.04 & 62.83 & 68.34 & 83.02 & 113.42 & 62.22 & 3.02 & 0 \\
\hline $\mathrm{Q}\left(\mathrm{m}^{3} / \mathrm{s}\right)$ & 0 & 1.04 & 0 & 3.81 & 19.30 & 24.23 & 26.36 & 32.02 & 43.75 & 24.00 & 1.16 & 0 \\
\hline
\end{tabular}

These hydrological parameters $\left(\mathrm{H}_{\mathrm{p}}, \mathrm{W}_{\mathrm{me}}\right.$ and $\left.\mathrm{Q}\right)$ of the Kalako waterfall are represented by hydrographs, see Figures 2,3 and 4.
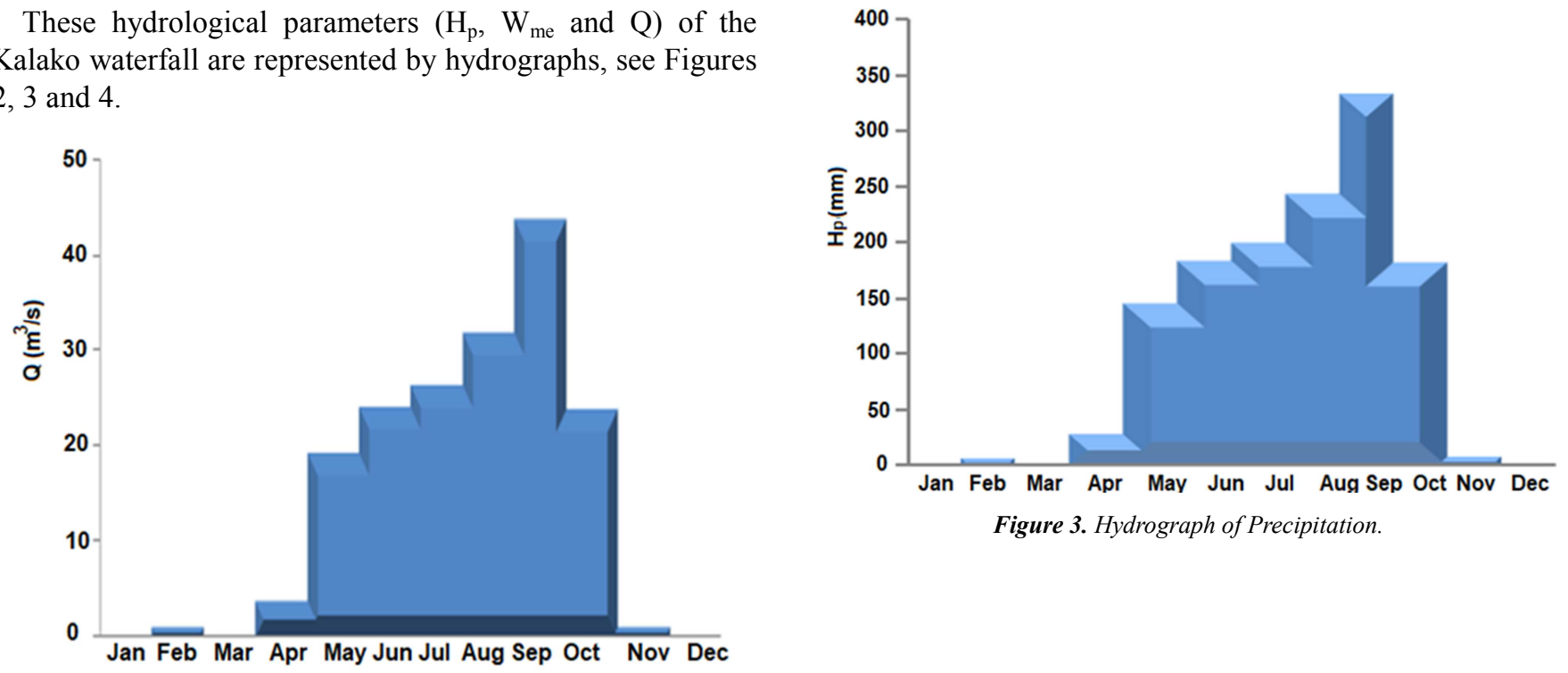

Figure 3. Hydrograph of Precipitation.

Figure 2. Hydrograph of Monthly Flow. 


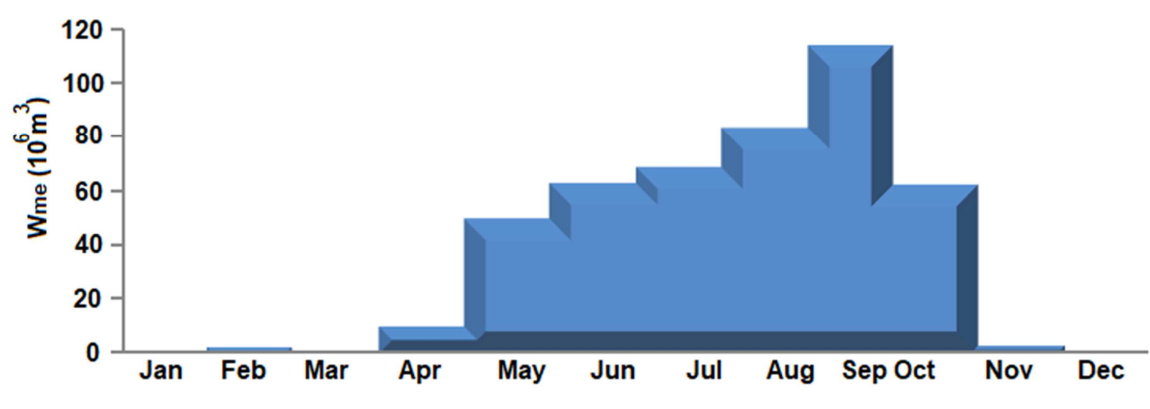

Figure 4. Hydrograph of the monthly volumes of the year of calculation

\subsection{Discussion}

Figures 1, 2 and 3 show that:

(1) During the calculation year, the values of the hydrological parameters (rainfall heights, flow volume and monthly flow) of the Kalako site are zero in the months of December, January and March.

(2) The values of the hydrological parameters of the site are minimal during the months of February $(8.0 \mathrm{~mm}$, $2.72 \times 10^{6} \mathrm{~m}^{3}$ and $\left.1.04 \mathrm{~m}^{3} / \mathrm{s}\right)$, April $\left(29.1 \mathrm{~mm}, 9.89 \times 10^{6}\right.$ $\mathrm{m}^{3}$ and $\left.3.81 \mathrm{~m}^{3} / \mathrm{s}\right)$ and November $\left(8.9 \mathrm{~mm}, 3.02 \times 10^{6}\right.$ $\mathrm{m}^{3}$ and $\left.1.16 \mathrm{~m}^{3} / \mathrm{s}\right)$. This results in a very small amount of water during these periods.

(3) During the period from May to October, the hydrological parameters of the site are significant, with the maximum values observed in September (333.42 $\mathrm{mm}, 113.02 \times 10^{6} \mathrm{~m}^{3}$ and $43.75 \mathrm{~m}^{3} / \mathrm{s}$ ).

These results show that, during the calculation year, seven (7) months (April, May, June, July, August, September and October) out of twelve (12) of the Kalako site are very favorable for the production of energy. hydroelectric.

\section{Conclusion}

This research made it possible to determine all the hydrological parameters of the Kalako waterfall on the Tinkisso river in Dabola, thus contributing to the knowledge of the characteristics allowing to evaluate the hydro-energetic potential of this site. The supply of permanent electrical energy requires the installation of another system to overcome the deficit observed during the period of low water (January, February, March, November and December).

\section{References}

[1] Laure LEBECHEREL, 2015. Sensibilité des calculs hydrologiques à la densité des réseaux de mesure hydrométrique et pluviométrique, Doctorat ParisTech, 280p.
[2] L. Lebecherel, V. Andréassian, C. Perrin, P., 2014. Maugis, Analyse de la sensibilité des calculs hydrologiques à la densité spatiale des réseaux hydrométriques La Houille Blanche, ${ }^{\circ} 1$, p. 39-44.

[3] Sédibinet S., Sayon O., l'Eau en Guinée, 2017. Centre Observation, de Surveillance et Information Environnementales (COSIE), Conakry, 28p.

[4] Oumar NDIAYE, 2011. Etude de la faisabilité de la restauration et de la gestion durable des écosystèmes du haut Tinkisso, 30p.

[5] Organisation Météorologique Mondiale, 1994. Guide des pratiques hydrologiques, Acquisition et Traitement des données, Analyses, Prévision et autres applications, 5ème édition, $829 \mathrm{p}$.

[6] Hervé Abdi, 2010. Coefficient of Variation, In Neil Salkind (Ed.), Encyclopedia of Research Design. Thousand Oaks, CA: Sage, $5 \mathrm{p}$.

[7] Fábio Lourenço ROMANO, Gláucia Maria Bovi AMBROSANO, Maria Beatriz Borges de Araújo MAGNANI, Darcy Flávio NOUER, 2005. Analysis of the coefficient of variation in Shear and Tensile Bond Strength tests, J Appl Oral Sci., 13(3): 243-246.

[8] DIALLO Abdoul Gadiri Pounthioun, 1996. Projet de Construction d'une Centrale Hydroélectrique sur le site de Fouguia/Banko (Dabola), UGAN/Conakry.

[9] Houari Zeggane1 et Djamel Boutoutaou, 2017. Etude Régionale des Pluies Maximales Journalières Annuelles Fréquentielles du Centre nord d'Algérie Lebanese Science Journal, Vol. 18, No. 2, 166-179.

[10] M. PELOUX HUG, 2017. Méthodologie et détail des calculs hydrologiques, I. E. S Ingénieurs Conseil, 9p.

[11] Mr SEBBAR Abdelali Etude de la variabilité et de l'évolution de la pluviométrie au Maroc (1935-2005), 2013. Réactualisation de la carte des précipitations. Thèse de Doctorat, décembre, Université Hassan II Mohammedia Casablanca 188p.

[12] P. Chaperon, 1976. Estimation du volume des apports annuels des bassins versants, Fort de France, $13 \mathrm{p}$. 